\title{
Tips, Stalks, Tubes: Notch-Mediated Cell Fate Determination and Mechanisms of Tubulogenesis during Angiogenesis
}

\author{
Jennifer J. Tung ${ }^{1}$, Ian W. Tattersall ${ }^{1}$, and Jan Kitajewski \\ Department of Obstetrics/Gynecology and Pathology, Herbert Irving Comprehensive Cancer Center, \\ Columbia University Medical Center, New York, New York 10032 \\ Correspondence: jkk9@columbia.edu
}

\begin{abstract}
Angiogenesis is the process of developing vascular sprouts from existing blood vessels. Luminal endothelial cells convert into "tip" cells that contribute to the development of a multicellular stalk, which then undergoes lumen formation. In this review, we consider a variety of cellular and molecular pathways that mediate these transitions. We focus first on Notch signaling in cell fate determination as a mechanism to define tip and stalk cells. We next discuss the current models of lumen formation and describe new players in this process, such as chloride intracellular channel proteins. Finally, we consider the possible medical therapeutic benefits of understanding these processes and acknowledge potential obstacles in drug development.
\end{abstract}

\section{NOTCH SIGNALING: PERSPECTIVE AND MECHANISM}

$T^{\mathrm{h}}$ he Notch gene was first described in 1917 when Thomas Hunt Morgan isolated a mutant allele in Drosophila melanogaster that caused a characteristic notching of their wings (Morgan 1917). Since then, Notch, and the signaling pathway to which it lends its name, has been shown to be a highly conserved mechanism of cell fate determination and differentiation, involved in processes as diverse as neurogenesis (de la Pompa et al. 1997), limb development (Jiang et al. 1998), and arteriovenous specification (Lawson et al. 2001; Zhong et al. 2001; Shawber et al. 2003). Notch signaling involves interactions between adjacent ligand- and receptor-expressing cells, and the juxtacrine nature of this interaction allows Notch to stimulate different processes in neighboring cells, a difficult distinction to make with soluble ligand gradients or other common signal archetypes.

Notch encodes a single-pass transmembrane receptor, which is processed posttranslationally by furin-like proteases (Weinmaster 1998) before being expressed on the cell surface as a heterodimeric, noncovalent coupling of extracellular and intracellular domains. The extracellular domain consists of 36 EGF-like repeats, which interact with similar EGF-like repeats on Notch ligands (Wharton et al. 1985; Vässin

\footnotetext{
${ }^{1}$ These authors contributed equally to this work. Editors: Michael Klagsbrun and Patricia D'Amore Additional Perspectives on Angiogenesis available at www.perspectivesinmedicine.org Copyright (C) 2012 Cold Spring Harbor Laboratory Press; all rights reserved; doi: 10.1101/cshperspect.a006601 Cite this article as Cold Spring Harb Perspect Med 2012;4:a006601
} 
J.J. Tung et al.

et al. 1987; Thomas et al. 1991). Though Notch ligands are also single-pass transmembrane proteins, they lack a substantial intracellular domain, and evidence for autonomous signaling in ligand-expressing cells remains controversial (Hoyne et al. 2010). The Drosophila genome contains a single Notch receptor gene and two genes encoding Notch ligands Delta and Serrate. Mammals possess four Notch homologs, named Notch 1 through 4, and five ligands, some of which are similar to Delta (Delta-like 1,3 , and 4), and some of which resemble Serrate (Jagged 1 and 2) (Weinmaster et al. 1991; Weinmaster et al. 1992; Lardelli et al. 1994; Bettenhausen et al. 1995; Lindsell et al. 1995; Shawber et al. 1996a; Uyttendaele et al. 1996; Dunwoodie et al. 1997; Gallahan and Callahan 1997).

Notch signaling is initiated when a Notch family receptor binds one of its ligands. The ligand's membrane-bound localization is a core concept of Notch signaling, and although free ligand has been suggested to stimulate Notch signaling (Hicks et al. 2002), soluble forms of Notch ligands have been shown to competitively inhibit signaling by sequestering Notch receptors (Small et al. 2001; Dikic and Schmidt 2010). There is even some suggestion that exosomal release of free Notch ligands may function in a physiological setting to inhibit Notch signaling and stimulate blood vessel outgrowth (Sheldon et al. 2010).

Ligand binding results in double cleavage of the Notch receptor by ADAM-family proteases, such as ADAM10 or ADAM17 (Brou et al. 2000; Hartmann et al. 2002; Bozkulak and Weinmaster 2009), and by the $\gamma$-secretase/presenilin complex (reviewed in Fortini 2001). This cleavage untethers the Notch intracellular domain, which translocates to the nucleus and converts the transcriptional repressor complex CSL to a transcriptional activator (Jarriault et al. 1995; Weinmaster 1998; Lai 2002). The Notch/CSL complex in turn up-regulates the expression of gene targets such as Hair/Enhancer of Split (HES) and HES-related genes (Jarriault et al. 1995). Additionally, studies comparing the effects of CSL-disabling mutations to those of Notch receptor deletion have suggested a role for a CSL-independent pathway of Notch activity that operates through a distinct set of molecules, such as the transcription factor Deltex (Shawber et al. 1996b; Matsuno et al. 1997; Nofziger et al. 1999; Martinez Arias et al. 2002). Although the physiological significance of this noncanonical Notch signaling is unclear, it is important to keep in mind when interpreting data from experiments that employ mutation of CSL components (such as CBF1/RBP-J к) as a proxy for complete Notch signaling ablation.

\section{NOTCH SIGNALING IN ANGIOGENESIS: THE TIP/STALK MODEL}

The role of Notch signaling in vessel sprouting provides an elegant example of classical Notchmediated cell fate determination. The current model of endothelial angiogenesis centers on the interplay between "tip" and "stalk" cell characters, and Notch signaling is central to the establishment of these identities (Fig. 1). A new angiogenic sprout begins when extracellular vascular endothelial growth factor A (VEGF-A) binds VEGF receptor 2 (VEGFR-2) on an endothelial cell, causing up-regulation of the Notch ligand Delta-like 4 (Dll4). Membrane-bound Dll4 interacts with Notch1 receptors on adjacent endothelial cells. This leads to the down-regulation of VEGFR-2 in those cells, creating a situation in which one cell expresses high VEGFR-2 levels and its neighbors are rendered less sensitive to VEGF-A signaling (Jakobsson et al. 2010). In addition, Notch receptor signaling also drives greater expression of VEGFR-1, which is a high-affinity, low-activity receptor that serves as a competitive inhibitor of VEGF signaling (Funahashi et al. 2010), further widening the VEGF response gap between neighboring cells.

The cell expressing VEGFR-2 and Dll4 becomes a nonproliferative "tip" cell. It produces filopodia that extend into the environment, and the tip cell undergoes chemotaxis toward angiogenic factors. The Notch-expressing neighbors of the tip cell become "stalk" cells that proliferate and contribute to the elongation of the nascent sprout. These stalk cells will ultimately lumenize to form a functional blood 
Tips, Stalks, and Tubes

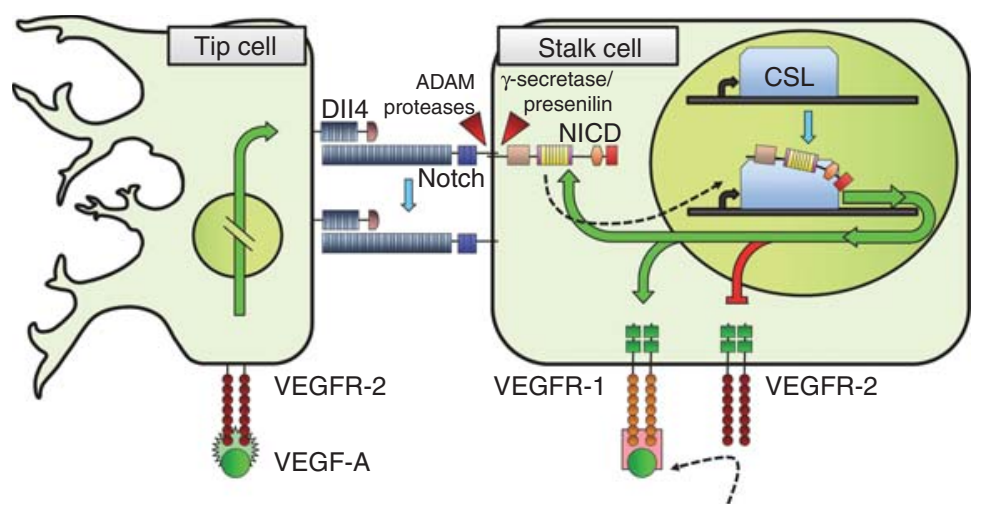

Figure 1. Notch and VEGF signaling regulate endothelial tip cell formation. In future tip cells, VEGF-A signaling via VEGFR-2 causes up-regulation of Dll4. Dll4 binds Notch molecules on the membranes of adjacent endothelium and facilitates receptor cleavage by ADAM and $\gamma$-secretase/presenilin. Cleavage untethers the Notch intracellular domain (NICD) from the membrane, which then translocates to the nucleus and complexes with CSL, turning the erstwhile transcriptional repressor into a transcriptional activator. This has a number of downstream effects, including the creation of a positive feedback loop via increased Notch expression, inhibition of VEGFR-2 expression, and up-regulation of VEGFR-1, a receptor with high affinity for VEGF-A but low signaling activity. Thus, endothelial cells adjacent to tip cells have greatly reduced sensitivity to VEGF-A, and adopt a stalk cell character.

vessel, a process that we will discuss in more depth. Perivascular cell recruitment is the last step in creating a fully functional blood vessel. Recently, a combination of genetic and computational models has revealed that competition for tip cell identity is a dynamic process in which cells transition between tip and stalk cell identities throughout the growth of the vessel (Jakobsson et al. 2010).

\section{MECHANISMS OF ENDOTHELIAL LUMEN FORMATION}

An essential step of vasculogenesis and angiogenesis is tubulogenesis, the process of lumen formation. Without tubulogenesis, endothelial cords would fail to transport fluid and key components of blood. Although it is accepted that endothelial tubulogenesis involves the establishment of apicobasal polarity, interactions with the extracellular matrix, and cytoskeletal reorganization, the underlying mechanisms of tubulogenesis are still unclear (Hogan and Kolodziej 2002; Lubarsky and Krasnow 2003; Dejana 2004; Bryant and Mostov 2008; Iruela-Arispe and Davis 2009; Zeeb et al.
2010; Datta et al. 2011). Recent studies have implicated a broad array of cell surface and signaling proteins in tubulogenesis, and several models have been proposed to explain the mechanics of tubulogenesis.

An initial model for endothelial tubulogenesis, referred to as "cell hollowing," involves the coalescence of pinocytic vesicles to generate lumens (see Fig. 2) (Wolff and Bar 1972; Folkman and Haudenschild 1980; Davis and Camarillo 1996; Kamei et al. 2006; Davis et al. 2007). This model emphasizes the importance of vesicular and vacuolar development and movement within the endothelial cell. By cell hollowing, a single endothelial cell creates a de novo lumen through the coalescence of vesicles/vacuoles intracellularly while cell invasion into the surrounding stroma occurs. These vesicles carry apical markers to distinguish the future lumenal membrane from the basal membrane of the endothelial cell, and this process occurs without cell loss (Wolff and Bar 1972). Once the cell is "hollowed," the lumen contained within the cell opens on either end through intercellular vacuolar fusion by exocytosis to form a "seamless vessel" without junctions (Kamei et al. 
J.J. Tung et al.

Cell hollowing

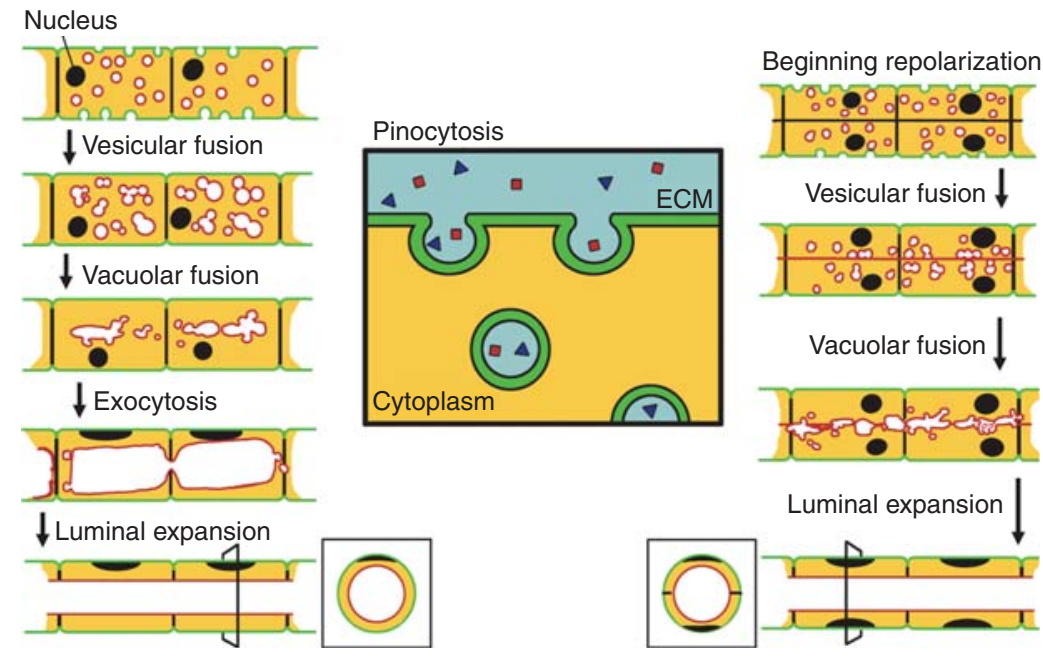

Figure 2. Cell hollowing and cord hollowing models for tubulogenic mechanisms. In this depiction, green shading represents the basal domain of the cell whereas red shading represents the apical domain. (Center panel) Representation of the process of pinocytosis. (Left panel) Cell hollowing begins with a cord of endothelial cells undergoing pinocytosis. The resultant pinocytic vesicles then fuse intracellularly to form vacuoles, which further fuse. Apical markers on the vacuolar membrane target the vacuoles to the site of the future lumen while the vacuoles continue to fuse, creating a membrane bound lumen. The lumen of this "hollowed cell" then fuses intercellularly with surrounding hollowed cells by exocytosis of vacuoles to form a continuous lumen. A cross section of a vessel formed in such a manner would reveal a vessel without cell junctions, or a "seamless vessel." (Right panel) During invasion by an endothelial cord into the surrounding extracellular matrix, the endothelial cells lose their apicobasal polarity in the cord-hollowing model. An external cue then triggers repolarization and membranes contacting the extracellular matrix accumulate basal markers while pinocytic vesicles carrying apical markers fuse at the site of the future lumen. Vesicles continue to fuse at the apical domain creating "pockets of lumen" that eventually merge to become a continuous lumen.

2006). Evidence for this model is found most notably in vitro and by analysis of zebrafish intersomitic vessel sprouting (Folkman and Haudenschild 1980; Davis and Camarillo 1996; Kamei et al. 2006).

An alternative model for endothelial tubulogenesis, known as "cord hollowing" and schematized in Figure 2, emphasizes the importance of endothelial cell-cell junctions and the establishment of apicobasal polarity (Pollack et al. 1998; Parker et al. 2004; Jin et al. 2005; Wang et al. 2010). In this model, a polarized multicellular endothelial cord migrates into the surrounding stroma and loses its apicobasal polarity. During this step, cell junctions in the cord break and the cord thickens to roughly two or three cells. A de novo lumen is formed extracellularly without cell loss when an external cue signals for repolarization, and surfaces in contact with the extracellular matrix accrue basal markers whereas apical markers target endothelial cell-cell junctions at the central axis via vesicles. Apical vesicles then fuse at the central axis, separating the cell surfaces with fluid-filled pockets of what will ultimately be a lumen continuous within itself and the parent vessel. Studies using Caenorhabditis elegans and zebrafish provide notable data supporting this model (Leung et al. 1999; Parker et al. 2004; Jin et al. 2005; Wang et al. 2010).

In both the cell hollowing and cord hollowing models, vesicular trafficking plays a role (Folkman and Haudenschild 1980; Davis and Camarillo 1996; Iruela-Arispe and Davis 2009). The origin and purpose of these vesicles remains under contention, but one family of 
Tips, Stalks, and Tubes

proteins has recently been implicated as having a role in this process: chloride intracellular channels (CLICs). CLICs are putative ion channels belonging to the p64 gene family and are distantly related to GSTs. They exist as both soluble cytoplasmic proteins and membrane bound channel proteins with a putative transmembrane domain near the amino terminus, making them unique as mammalian ion channels (Redhead et al. 1997; Berry and Hobert 2006). Of the six known mammalian CLICs, only CLIC1 and CLIC4 are expressed highly in endothelial cells (Suh et al. 2005; Money et al. 2007; Suh et al. 2007; Ulmasov et al. 2007; Tung et al. 2009; Tung and Kitajewski 2010; Wegner et al. 2010). In addition, CLIC5 levels are found to be low in placental endothelial cells (Money et al. 2007) and high in glomerular endothelial cells (Wegner et al. 2010). CLIC1, CLIC4, and CLIC5 are also regulated by F-actin when reconstituted in planar lipid bilayers (Singh et al. 2007), suggesting a potential role in cytoskeletal reorganization.

Little attention has been given to CLIC5 as a regulator of tubulogenesis thus far, but there is increasing evidence for a role for CLIC4 in lumen formation. CLIC4 has been found to be localized to vesicles in human umbilical vein endothelial cells (Bohman et al. 2005) and large vacuoles in mouse heart endothelial cells (Ulmasov et al. 2009). In vitro, CLIC4 promotes endothelial proliferation, network formation, capillary-like sprouting, and lumen formation (Tung et al. 2009). Analyses of retinal vasculature in developing mice, and in adult mice challenged by an oxygen toxicity assay, reveals stunted vascular development in $\mathrm{clic}^{-/-}$ mice (Ulmasov et al. 2009). CLIC4 may also influence vacuolar formation in endothelial cells by regulating $\mathrm{pH}$ (Ulmasov et al. 2009). Furthermore, CLIC4 localizes to the midbody and centrosome of cultured bovine aortic endothelial cells and is enriched at cell-cell junctions in choriocarcinoma cells (Berryman and Goldenring 2003), suggesting a role in establishing or maintaining cell polarization. CLIC4 is also RhoA-regulated in a variety of cells (Ponsioen et al. 2009). On $\mathrm{G}_{13}$-coupled Rho-A activating receptor stimulation, CLIC4 translocates to the plasma membrane but does not modulate chloride currents, implying a hitherto unknown function of CLIC4 in the cell. Although not necessarily an effector of tubulogenesis, CLIC1 is also receiving attention as being a potential regulator of angiogenesis. In vitro CLIC1 plays a role in endothelial cell migration, proliferation, and branching morphogenesis; however, no notable effect on lumen formation results from knocking down CLIC1 levels (Tung and Kitajewski 2010). CLIC1 may also affect apical membrane recycling as it is localized to the apical domain in several columnar epithelia (Ulmasov et al. 2007).

In addition to the cell hollowing and cord hollowing models, other models of tubulogenesis have been proposed. Each model has supporting evidence and utility in explaining the mechanics behind endothelial tubulogenesis. One recent study of the developing mouse aorta proposes a mechanism by which lumens are formed extracellularly when VEGF-A activates a chain of events leading to F-actin rearrangements that ultimately separate two contacting endothelial cells (Strilic et al. 2009). This process involves Rho-dependent kinase and is not known to invoke vesicular trafficking. Another model, termed "selective sprouting," is supported by studies in the developing zebrafish cardinal vein (Herbert et al. 2009). The selective sprouting model stipulates that venous endothelial cells migrate from the dorsal aorta to surround erythrocytes and are retained by VEGF-A/VEGFR-2 signaling, a process analogous to vasculogenesis during embryogenesis.

Although these models for tubulogenesis may emphasize the importance of different cellular and molecular components, several elements are integral and common. For instance, most models include the establishment of apicobasal polarity and cytoskeletal reorganization. The basal domain of the cell is defined as the domain that contacts the extracellular matrix, whereas the apical domain marks the location of lumen formation. The formation of polarized cells has been well studied and reviewed in detail (Hogan and Kolodziej 2002; Lubarsky and Krasnow 2003; Macara 2004; Goldstein and Macara 2007; Bryant and Mostov 
J.J. Tung et al.

2008; Zeeb et al. 2010). We will briefly cover several endothelial polarity proteins implicated in tubulogenesis: Cdc42, the Par3/6/aPKC complex, and F-actin. These proteins are integral in establishing polarity reorientation during cell division and directed cell migration (Etienne-Manneville 2004; Osmani et al. 2010). Cdc42 is critical for the tubulogenic process (Bayless and Davis 2002; Davis et al. 2007; Koh et al. 2008) when assayed using cultured endothelial cells. Furthermore, Cdc42 expression in vacuolated endothelial cells is expressed in a polarized perinuclear and pericentrosomal fashion (Koh et al. 2008). The Cdc42-dependent polarity pathway involves established polarity proteins Par3, Par6, and aPKC, which are known to contribute to endothelial tubulogenesis (Joberty et al. 2000; Davis et al. 2007). Evidence for a Cdc42 requirement in tubulogenesis has been shown in vitro and in vivo (Kamei et al. 2006; Koh et al. 2008; Kesavan et al. 2009); however, a recent study suggests a VE-cadherin-dependent mechanism for establishing polarity (Strilic et al. 2009) and reports cell polarization in the developing mouse aorta without Cdc42 effector activation. Instead the authors propose that F-actin is recruited in a VE-cadherin-dependent manner to the luminal surface to establish polarity. F-actin is apically localized during cat corneal endothelial wound healing (Petroll et al. 1995), and altering F-actin results in erratic vascular lumenization (Cattelino et al. 2003), which supports the role of cytoskeletal reorganization in forming and maintaining angiogenic sprouts (Bayless and Johnson 2011). Proper microtubule architecture is also necessary for maintaining capillary-like tubes in vitro (Connolly et al. 2002; Bayless and Davis 2004).

Endothelial cell association with the extracellular matrix is an important component in tubulogenesis (Stupack and Cheresh 2002). Integrins have been implicated in tubulogenesis as they regulate cell morphology and interact with both the cell cytoskeleton and extracellular matrix. Several integrins expressed in endothelial cells function in angiogenesis including $\alpha 1 \beta 1, \alpha 2 \beta 1, \alpha 4 \beta 1, \alpha 5 \beta 1, \alpha 6 \beta 1, \alpha 6 \beta 4, \alpha 9 \beta 1$, $\alpha v \beta 3$ and $\alpha v \beta 5$ (Rupp and Little 2001; Stupack and Cheresh 2004; Avraamides et al. 2008; Garmy-Susini and Varner 2008). In particular, the $\beta 1$ integrin subunit functions in establishing arteriolar polarity of midsized arteries during lumen formation and acts upstream of Par3, but not Par6 and aPKC (Zovein et al. 2010). It should be noted that $\beta 1$ ablation does not affect tubulogenesis in single-cell capillaries, nor does it affect vasculogenesis (Tanjore et al. 2008; Zovein et al. 2010). In vivo, quails injected with $\beta 1$-blocking antibody fail to form proper dorsal aortas (Drake et al. 1992), and injection of $\alpha v \beta 3$ integrin antibody into developing quail embryos blocks lumen formation (Drake et al. 1995). $\beta 3$ integrin-null mice show disrupted vacuolar patterning and atypical lumenization in their coronary capillaries (Weis et al. 2007). Focal adhesion kinase (FAK) associates with both integrins and growth factor receptors, and clearly plays a role in establishing cell polarity (Lim et al. 2010).

The fact that several models of endothelial tubulogenesis are supported by a variety of observations and experiments suggests that the mechanism used for lumen formation could be context-dependent. To further our understanding of tubulogenesis, scientists have developed several means for analyzing angiogenesis: in vitro assays that mimic individual steps of angiogenesis, ex vivo assays, and the utilization of mice, C. elegans, zebrafish, and D. melanogaster model organisms. In vitro, the most modern and relevant assays strive to mimic the entire vessel-building process. One assay mimics capillary sprouting from endothelial cells attached to dextran-coated Cytodex beads (Nakatsu et al. 2003; Nakatsu et al. 2007), as shown in Figure 3. In this assay, the endothelial cell-coated beads are embedded in a fibrin clot with an overlaying monolayer of fibroblasts. Capillary-like sprouts form and migrate into the fibrin clot, ultimately elongating, anastomosing, and forming quantifiable lumens (Nakatsu et al. 2003; Nakatsu et al. 2007). Another in vitro assay uses both pericytes and endothelial cells to form a patent vessel in collagen, with evidence of basement membrane formation (Stratman et al. 2009). In this assay, endothelial cells and pericytes are cocultured 


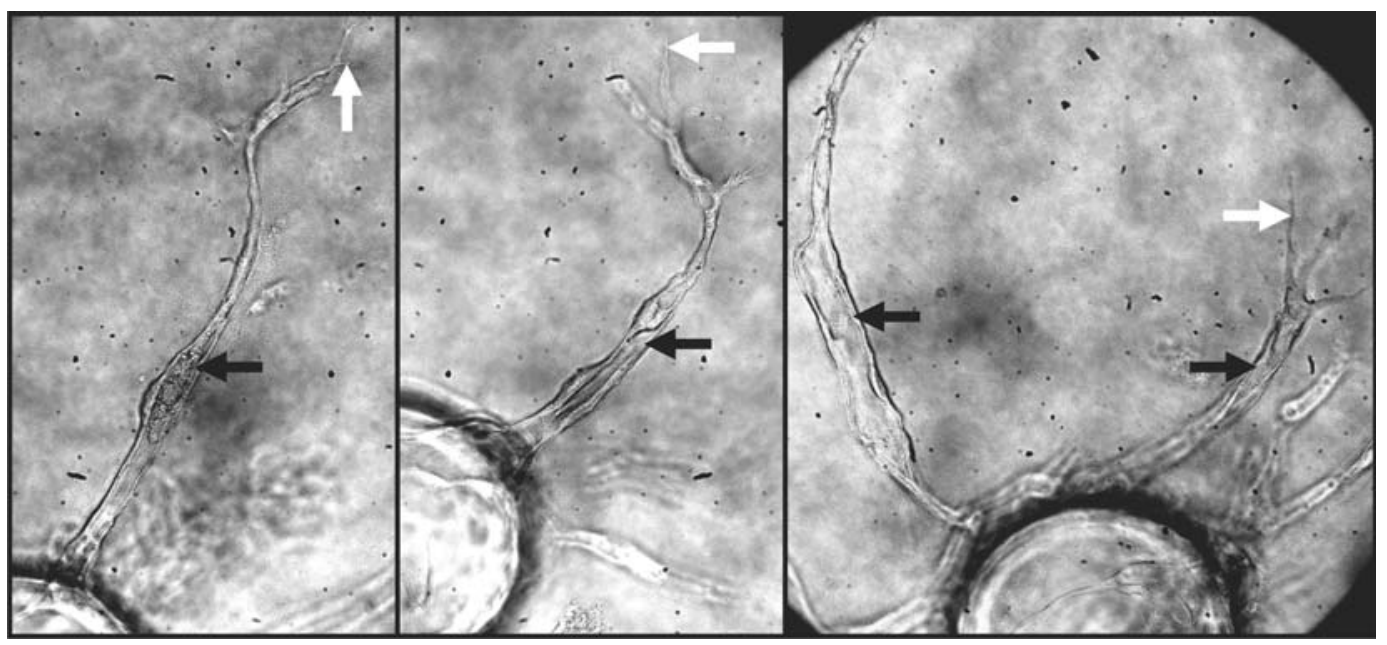

Figure 3. Viewing vessel anatomy in a fibrin bead assay. Microscopic evaluation of a fibrin bead assay shows large, continuous lumens (black arrows) in sprouts that have migrated out into the fibrin clot. Filopodia from the leading tip cell are also visible in this assay (white arrows).

in a three-dimensional collagen gel with special medium. Endothelial cells migrate toward each other and form de novo lumen-containing, tube-like structures, and pericytes are recruited to promote and stabilize these structures.

The C. elegans excretory canal and D. melanogaster trachea are thought to develop lumens in an analogous way to human blood vessels and thus can be drawn on to help analyze angiogenic phenotypes (Buechner 2002; Lubarsky and Krasnow 2003; Sullivan and Bicknell 2003). For in vivo analyses of angiogenic phenotypes, one of the most common means of studying angiogenic defects is to look at a transgenic mouse retina. The mouse retina is thought to recapitulate the sprouting process starting from neovasculogenesis to the final recruitment of mural cells. A clear advantage of the retina is that different stages of angiogenic development are well characterized and defined by time after birth (Fruttiger 2002; Uemura et al. 2006; Stahl et al. 2010). Like the mouse, developing zebrafish provide an excellent means of studying angiogenesis as its subintestinal, intersomitic, and brain vasculature development are very well-characterized and thought to be analogous to human blood vessel lumen formation (Serbedzija et al. 1999). Indeed with further research and advancing means for studying tubulogenesis, we may find that lumen formation results from a combination of proposed models or that the method for tubulogenesis depends on vessel type and caliber.

\section{NOTCH SIGNALING IN TUMOR ANGIOGENESIS: BENEFITS AND COMPLICATIONS}

Since Judah Folkman first proposed the idea in 1971 (Folkman 1971), it has been increasingly appreciated that tumor cells rely on the recruitment of host vasculature to provide nourishment and facilitate waste removal. These processes are critical to the rapid proliferation and dissemination characteristic of malignant cancer, and because of this, induction of angiogenesis is recognized as an important facet of progression and metastasis in most solid tumors.

Accordingly, a great deal of recent drug development has been targeted at the disruption of angiogenesis. Unfortunately, the initial efforts to treat human cancer with VEGF blockade, most notably employing the anti-VEGF-A antibody bevacizumab (Avastin), have been frustrated by the rapid evolution of resistance 
J.J. Tung et al.

to the drug (Jain et al. 2006). There have been some notable clinical successes attributed to VEGF blockade, and Avastin is approved for treatment of colon and renal cancers; however, many cancers that clearly require vascularization are highly resistant to VEGF-A blockade from the start (Jain et al. 2006; Shojaei et al. 2007). In addition, many others acquire such resistance, casting some doubt both on the therapeutic benefit of VEGF-A blockade and on the factor's indispensability in angiogenesis. Drug developers have more recently sought to target other known angiogenic pathways, pursuing therapies that might be useful independently or in concert with VEGF blockade in the treatment of cancer.

Notch signaling has attracted interest as a therapeutic target in cancer for several distinct reasons. Initially, Notch signaling was suggested to be important as a survival factor in cancer stem cells, and combination treatment with ionizing radiation and Notch inhibition has shown some promise as a method for destroying tumor mass while inhibiting its regrowth. Modulation of Notch as a means of targeting cancer stem cells is well reviewed (Rizzo et al. 2008). In addition, oncogenic mutation of Notch has been recognized as a key event in the pathogenesis of certain cancer types, notably T-cell acute lymphoblastic leukemia (T-ALL) (Weng et al. 2004; Palomero et al. 2006). Though Notch signaling modulation may be an effective tool in all of these scenarios, this article will focus on the involvement of Notch in tumor angiogenesis, and efforts directed at inhibiting this facet of its activity.

The Notch pathway was implicated in tumor angiogenesis when the human Notch ligand Delta-like 4 (DLL4) was found to be up-regulated in tumor blood vessels in several types of cancer (Mailhos et al. 2001; Patel et al. 2005; Patel et al. 2006). Given the Notch pathway's close association with the VEGF pathway, it was thought that this up-regulation might somehow contribute to VEGF-independent angiogenesis, and several groups subsequently investigated the effects of Dll4 inhibition on physiological angiogenesis in mouse models. They found that its effects matched those predicted by the tip/stalk model (Noguera-Troise et al. 2006; Ridgway et al. 2006; Scehnet et al. 2007). When Dll4 is sequestered, Notch signaling in all endothelial cells remains low, as do VEGFR-1 levels. This results in many VEGF-A-sensitive cells that can adopt "tip" cell character and leads to a characteristic hypersprouting and overproliferation of endothelial cells. Paradoxically, this does not lead to greater perfusion, but rather to tissue ischemia. By inhibiting Notch signaling, the entire process of blood vessel formation is disrupted such that although there are more endothelial branches, the vessels formed are friable, weak, and do not function properly (Noguera-Troise et al. 2006; Ridgway et al. 2006; Scehnet et al. 2007; Thurston et al. 2007). Initial studies have indicated that combination VEGF-A and Dll4 blockade may have synergistic effects in the treatment of some tumors (Ridgway et al. 2006; Li et al. 2007), and investigation in this field is ongoing.

Although Notch is vital in angiogenesis, initial investigation of Notch signal inhibition has highlighted a number of side effects that may limit its potential as a therapeutic target. Longterm blockade of Dll4 in several mammalian models was found to cause hemorrhage-prone liver hemangiomas (Li et al. 2010; Yan et al. 2010; Ryeom 2011), likely because of development of the same overproliferated, delicate vessels seen elsewhere. Although angiogenesis is not widespread in adults, the liver is a highly vascular organ that regenerates frequently, so it is not surprising that it is impacted by angiogenic dysfunction. Pathological changes were detected in the liver by as little as 8 weeks of treatment (Yan et al. 2010). Dll4 blockade may therefore be useful only as a short-term treatment regimen. Notch blockade via systemic treatment with $\gamma$-secretase inhibitors such as dibenzazipine (DBZ) causes dose-dependent intestinal metaplasia in animal models (Milano et al. 2004). Intestinal crypt stem cells rely on Notch signaling to govern daughter cell fate determination (Searfoss et al. 2003), and disruption of Notch in this context leads to overpopulation with mucus-secreting goblet cells, leading to malnutrition and diarrhea. 
Tips, Stalks, and Tubes

$\gamma$-secretase inhibition affects many different pathways; however, it has been shown that specific Notch inhibition can also cause this phenotype in certain circumstances (Wu et al. 2010). Future efforts to disrupt Notch signaling must seek to circumvent this side effect.

The future of Notch inhibition as a weapon against tumor angiogenesis is promising, and refinements in several aspects of drug function and delivery may help to alleviate the problems that have prevented its successful clinical application thus far. First, the exact nature of the role of Notch in angiogenesis is still being determined. Although we have a reasonable understanding of Notch's endothelial role in the tip/ stalk model, recent computer modeling shows us that we are just beginning to understand how dynamic these intercellular interactions truly are (Jakobsson et al. 2010). Additionally, the precise roles of Notch ligands are still being described, and recent work suggests that Dll4 and Jagged1 signaling may have opposing effects in angiogenesis, the former fostering tip cell genesis while the latter inhibits it (Benedito et al. 2009). Moreover, there are additional angiogenic activities ascribed to Jagged1 (High et al. 2008) and Dll1 (Liao et al. 2010) that may not necessarily be related to tip/stalk cell fate determination. Even beyond the endothelium, the creation of stable vessel networks relies on the input from many other cell types, including pericytes and tissue macrophages (Leibovich et al. 1987; Bjarnegard et al. 2004; Fantin et al. 2010; Schmidt and Carmeliet 2010), which may also depend on Notch signaling for aspects of their function. It may prove that the elements of Notch signaling that foster tumor angiogenesis are distinct from those that cause severe complications when inhibited, and that precise targeting of specific ligand isoforms may improve the therapeutic window of Notch inhibition therapy. Alternately, it may be possible simply to target drug delivery away from sites of complication, such as the intestinal mucosa. For instance, it is conceivable that certain therapy modalities, such as large protein constructs, may not freely diffuse through healthy vasculature. Thus, such a biological construct could theoretically be more active in the tissue surrounding the leaky vasculature of a tumor but functionally inactive in the intestine, avoiding unwanted collateral damage.

The recent development of a competitive "Notch1 decoy" inhibitor protein may help to increase our understanding of Notch signaling dynamics in a tumor setting while at the same time addressing many of the points set forth in the preceding section. The protein consists of the 36 EGF-like repeats of the Notch1 extracellular domain, fused to a human Fc domain. Initial work indicates that this protein construct is capable of acting as a competitive inhibitor of Notch signaling (Funahashi et al. 2008). Because different Notch ligands bind differently to their receptor, it is possible that further modification of this basic inhibitor design may generate competitive inhibitors of specific avenues of Notch signaling, allowing wellcontrolled analysis of the ligands' roles in tumor angiogenesis and providing a potentially useful mechanism of targeted pharmacological inhibition. Because the inhibitor is a relatively bulky protein construct, it is also possible that its tissue availability may differ from that of currently employed inhibiting antibodies and may show some of the inherent tumor tropism discussed above. Though further work is necessary to characterize the behavior of this construct, it represents a tantalizing new modality for the study and therapeutic modification of Notch signaling in the tumor microenvironment.

\section{CONCLUDING REMARKS}

Judah Folkman pioneered the idea of targeting angiogenesis in cancer therapeutics, and tumor angiogenesis is now a well-established component in developing tumor malignancy (Hanahan and Weinberg 2011). As tubulogenesis is an integral step in forming a fully functional vessel, advancing our understanding of basic tubulogenic mechanisms may provide a new avenue for anticancer drug development. Without a functional lumen, tumor-recruited blood vessels would neither be able to carry oxygen or necessary nutrients to the tumor nor effectively dispose of toxic waste products, leading to the inhibition and possible prevention of tumor 
J.J. Tung et al.

growth. Additionally, the lack of a competent vascular outflow tract removes a key avenue of metastasis, possibly limiting disease spread. Because tubuologenesis is a process associated with new vessel development and not established vessels, it is likely that antitubulogenic treatment would spare normal vessels and thus limit side effects.

Sprouting angiogenesis is a crucial component of many developmental and pathological processes. We have discussed many of the established and putative mechanisms underlying angiogenesis, from the VEGF/Notch interplay that establishes tip and stalk cell identity to the ion channels and signaling molecules that participate in tubulogenesis. We have discussed the translation of this basic scientific knowledge to useful clinical intervention and considered both the promises and challenges of antiangiogenic therapy. This is a vital and vibrant area of research that will continue to improve our understanding of fundamental human physiology and our ability to combat devastating disease.

\section{ACKNOWLEDGMENTS}

This work was supported by a grant to J.K. from the National Institutes of Health (NIH), 5RO1 HL062454. J.J.T. is supported by NIH training grant 2T32 CA09503 and I.W.T. by NIH MSTP training grant T32-GM07367. We thank Sean West for assistance with artwork.

\section{REFERENCES}

Avraamides CJ, Garmy-Susini B, Varner JA. 2008. Integrins in angiogenesis and lymphangiogenesis. Nat Rev Cancer 8: 604-617.

Bayless KJ, Davis GE. 2002. The Cdc42 and Racl GTPases are required for capillary lumen formation in threedimensional extracellular matrices. J Cell Sci 115: 1123-1136.

Bayless KJ, Davis GE. 2004. Microtubule depolymerization rapidly collapses capillary tube networks in vitro and angiogenic vessels in vivo through the small GTPase Rho. J Biol Chem 279: 11686-11695.

Bayless KJ, Johnson GA. 2011. Role of the cytoskeleton in formation and maintenance of angiogenic sprouts. J Vasc Res 48: 369-385.

Benedito R, Roca C, Sörensen I, Adams S, Gossler A, Fruttiger M, Adams RH. 2009. The notch ligands Dll4 and
Jagged1 have opposing effects on angiogenesis. Cell 137: 1124-1135.

Berry KL, Hobert O. 2006. Mapping functional domains of chloride intracellular channel (CLIC) proteins in vivo. J Mol Biol 359: 1316-1333.

Berryman MA, Goldenring JR. 2003. CLIC4 is enriched at cell-cell junctions and colocalizes with AKAP350 at the centrosome and midbody of cultured mammalian cells. Cell Motil Cytoskeleton 56: 159-172.

Bettenhausen B, Hrabě de Angelis M, Simon D, Guénet JL, Gossler A. 1995. Transient and restricted expression during mouse embryogenesis of Dll1, a murine gene closely related to Drosophila Delta. Development 121: 2407-2418.

Bjarnegard M, Enge M, Norlin J, Gustafsdottir S, Fredriksson S, Abramsson A, Takemoto M, Gustafsson E, Fassler R, Betsholtz C. 2004. Endothelium-specific ablation of PDGFB leads to pericyte loss and glomerular, cardiac and placental abnormalities. Development 131: 18471857.

Bohman S, Matsumoto T, Suh K, Dimberg A, Jakobsson L, Yuspa S, Claesson-Welsh L. 2005. Proteomic analysis of vascular endothelial growth factor-induced endothelial cell differentiation reveals a role for chloride intracellular channel 4 (CLIC4) in tubular morphogenesis. J Biol Chem 280: 42397-42404.

Bozkulak EC, Weinmaster G. 2009. Selective use of ADAM10 and ADAM17 in activation of Notchl signaling. Mol Cell Biol 29: 5679-5695.

Brou C, Logeat F, Gupta N, Bessia C, LeBail O, Doedens JR, Cumano A, Roux P, Black RA, Israël A. 2000. A novel proteolytic cleavage involved in Notch signaling: The role of the disintegrin-metalloprotease TACE. Mol Cell 5: 207-216.

Bryant DM, Mostov KE. 2008. From cells to organs: building polarized tissue. Nat Rev Mol Cell Biol 9: 887-901.

Buechner M. 2002. Tubes and the single C. elegans excretory cell. Trends Cell Biol 12: 479-484.

Cattelino A, Liebner S, Gallini R, Zanetti A, Balconi G, Corsi A, Bianco P, Wolburg H, Moore R, Oreda B, et al. 2003. The conditional inactivation of the $\beta$-catenin gene in endothelial cells causes a defective vascular pattern and increased vascular fragility. J Cell Biol 162: 1111-1122.

Connolly JO, Simpson N, Hewlett L, Hall A. 2002. Rac regulates endothelial morphogenesis and capillary assembly. Mol Biol Cell 13: 2474-2485.

Datta A, Bryant DM, Mostov KE. 2011. Molecular regulation of lumen morphogenesis. Curr Biol 21: R126-136.

Davis GE, Camarillo CW. 1996. An $\alpha 2 \beta 1$ integrindependent pinocytic mechanism involving intracellular vacuole formation and coalescence regulates capillary lumen and tube formation in three-dimensional collagen matrix. Exp Cell Res 224: 39-51.

Davis GE, Koh W, Stratman AN. 2007. Mechanisms controlling human endothelial lumen formation and tube assembly in three-dimensional extracellular matrices. Birth Defects Res C Embryo Today 81: 270-285.

de la Pompa JL, Wakeham A, Correia KM, Samper E, Brown S, Aguilera RJ, Nakano T, Honjo T, Mak TW, Rossant J, et al. 1997. Conservation of the Notch signalling pathway 
Tips, Stalks, and Tubes

in mammalian neurogenesis. Development 124: 11391148.

Dejana E. 2004. Endothelial cell-cell junctions: happy together. Nat Rev Mol Cell Biol 5: 261-270.

Dikic I, Schmidt MHH. 2010. Notch: Implications of endogenous inhibitors for therapy. Bioessays 32: 481-487.

Drake CJ, Davis LA, Little CD. 1992. Antibodies to $\beta 1$-integrins cause alterations of aortic vasculogenesis, in vivo. Dev Dyn 193: 83-91.

Drake CJ, Cheresh DA, Little CD. 1995. An antagonist of integrin $\alpha v \beta 3$ prevents maturation of blood vessels during embryonic neovascularization. J Cell Sci 108 (Pt 7): 2655-2661.

Dunwoodie SL, Henrique D, Harrison SM, Beddington RS. 1997. Mouse Dll3: A novel divergent Delta gene which may complement the function of other Delta homologues during early pattern formation in the mouse embryo. Development 124: 3065-3076.

Etienne-Manneville S. 2004. Cdc42-The centre of polarity J Cell Sci 117: 1291-1300.

Fantin A, Vieira JM, Gestri G, Denti L, Schwarz Q, Prykhozhij S, Peri F, Wilson SW, Ruhrberg C. 2010. Tissue macrophages act as cellular chaperones for vascular anastomosis downstream of VEGF-mediated endothelial tip cell induction. Blood 116: 829-840.

Folkman J. 1971. Tumor angiogenesis: Therapeutic implications. N Engl J Med 285: 1182-1186.

Folkman J, Haudenschild C. 1980. Angiogenesis in vitro. Nature 288: 551-556.

Fortini ME. 2001. Notch and presenilin: A proteolytic mechanism emerges. Curr Opin Cell Biol 13: 627-634.

Fruttiger M. 2002. Development of the mouse retinal vasculature: Angiogenesis versus vasculogenesis. Invest Ophthalmol Vis Sci 43: 522-527.

Funahashi Y, Hernandez SL, Das I, Ahn A, Huang J, Vorontchikhina M, Sharma A, Kanamaru E, Borisenko V, Desilva DM, et al. 2008. A Notch1 ectodomain construct inhibits endothelial notch signaling, tumor growth, and angiogenesis. Cancer Res 68: 4727-4735.

Funahashi Y, Shawber CJ, Vorontchikhina M, Sharma A, Outtz HH, Kitajewski J. 2010. Notch regulates the angiogenic response via induction of VEGFR-1. J Angiogenes Res 2: 3 .

Gallahan D, Callahan R. 1997. The mouse mammary tumor associated gene INT3 is a unique member of the NOTCH gene family (NOTCH4). Oncogene 14: 1883-1890.

Garmy-Susini B, Varner JA. 2008. Roles of integrins in tumor angiogenesis and lymphangiogenesis. Lymphat Res Biol 6: 155-163.

Goldstein B, Macara IG. 2007. The PAR proteins: Fundamental players in animal cell polarization. Dev Cell 13: 609-622.

Hanahan D, Weinberg RA. 2011. Hallmarks of cancer: The next generation. Cell 144: 646-674.

Hartmann D, de Strooper B, Serneels L, Craessaerts K, Herreman A, Annaert W, Umans L, Lübke T, Lena Illert A, von Figura K, et al. 2002. The disintegrin/metalloprotease ADAM 10 is essential for Notch signalling but not for $\alpha$-secretase activity in fibroblasts. Hum Mol Genet 11: $2615-2624$.
Herbert SP, Huisken J, Kim TN, Feldman ME, Houseman BT, Wang RA, Shokat KM, Stainier DY. 2009. Arterialvenous segregation by selective cell sprouting: An alternative mode of blood vessel formation. Science 326: 294-298.

Hicks C, Ladi E, Lindsell C, Hsieh JJ-D, Hayward SD, Collazo A, Weinmaster G. 2002. A secreted Delta1-Fc fusion protein functions both as an activator and inhibitor of Notch1 signaling. J Neurosci Res 68: 655-667.

High FA, Lu MM, Pear WS, Loomes KM, Kaestner KH, Epstein JA. 2008. Endothelial expression of the Notch ligand Jagged 1 is required for vascular smooth muscle development. Proc Natl Acad Sci 105: 1955-1959.

Hogan BL, Kolodziej PA. 2002. Organogenesis: Molecular mechanisms of tubulogenesis. Nat Rev Genet 3: 513-523.

Hoyne GF, Chapman G, Sontani Y, Pursglove SE, Dunwoodie SL. 2010. A cell autonomous role for the Notch ligand Delta-like 3 in $\alpha \beta$ T-cell development. Immunol Cell Biol 89: 696-705.

Iruela-Arispe ML, Davis GE. 2009. Cellular and molecular mechanisms of vascular lumen formation. Dev Cell 16: 222-231.

Jain RK, Duda DG, Clark JW, Loeffler JS. 2006. Lessons from phase III clinical trials on anti-VEGF therapy for cancer. Nat Clin Pract Oncol 3: 24-40.

Jakobsson L, Franco CA, Bentley K, Collins RT, Ponsioen B, Aspalter IM, Rosewell I, Busse M, Thurston G, Medvinsky A, et al. 2010. Endothelial cells dynamically compete for the tip cell position during angiogenic sprouting. Nat Cell Biol 12: 943-953.

Jarriault S, Brou C, Logeat F, Schroeter EH, Kopan R, Israel A. 1995. Signalling downstream of activated mammalian Notch. Nature 377: 355-358.

Jiang R, Lan Y, Chapman HD, Shawber C, Norton CR, Serreze DV, Weinmaster G, Gridley T. 1998. Defects in limb, craniofacial, and thymic development in Jagged 2 mutant mice. Genes Dev 12: 1046-1057.

Jin SW, Beis D, Mitchell T, Chen JN, Stainier DY. 2005. Cellular and molecular analyses of vascular tube and lumen formation in zebrafish. Development 132: 5199-5209.

Joberty G, Petersen C, Gao L, Macara IG. 2000. The cell-polarity protein Par6 links Par3 and atypical protein kinase C to Cdc42. Nat Cell Biol 2: 531-539.

Kamei M, Saunders WB, Bayless KJ, Dye L, Davis GE, Weinstein BM. 2006. Endothelial tubes assemble from intracellular vacuoles in vivo. Nature 442: 453-456.

Kesavan G, Sand FW, Greiner TU, Johansson JK, Kobberup S, Wu X, Brakebusch C, Semb H. 2009. Cdc42-mediated tubulogenesis controls cell specification. Cell 139: 791-801.

Koh W, Mahan RD, Davis GE. 2008. Cdc42- and Rac1mediated endothelial lumen formation requires Pak2, Pak4 and Par3, and PKC-dependent signaling. J Cell Sci 121: $989-1001$.

Lai EC. 2002. Keeping a good pathway down: Transcriptional repression of Notch pathway target genes by CSL proteins. EMBO Rep 3: 840-845.

Lardelli M, Dahlstrand J, Lendahl U. 1994. The novel Notch homologue mouse Notch 3 lacks specific epidermal growth factor-repeats and is expressed in proliferating neuroepithelium. Mech Dev 46: 123-136. 
J.J. Tung et al.

Lawson ND, Scheer N, Pham VN, Kim CH, Chitnis AB, Campos-Ortega JA, Weinstein BM. 2001. Notch signaling is required for arterial-venous differentiation during embryonic vascular development. Development 128: 3675-3683.

Leibovich SJ, Polverini PJ, Shepard HM, Wiseman DM, Shively V, Nuseir N. 1987. Macrophage-induced angiogenesis is mediated by tumour necrosis factor- $\alpha$. Nature 329: 630-632.

Leung B, Hermann GJ, Priess JR. 1999. Organogenesis of the Caenorhabditis elegans intestine. Dev Biol 216: 114-134.

Li JL, Sainson RC, Shi W, Leek R, Harrington LS, Preusser M, Biswas S, Turley H, Heikamp E, Hainfellner JA, et al. 2007. Delta-like 4 Notch ligand regulates tumor angiogenesis, improves tumor vascular function, and promotes tumor growth in vivo. Cancer Res 67: $11244-$ 11253.

Li JL, Jubb AM, Harris AL. 2010. Targeting DLL4 in tumors shows preclinical activity but potentially significant toxicity. Future Oncol 6: 1099-1103.

Liao S, Padera TP, Jain RK. 2010. Notch leads lymphatics and links them to blood vessels. Arterioscler Thromb Vasc Biol 30: 1682-1683.

Lim ST, Chen XL, Tomar A, Miller NL, Yoo J, Schlaepfer DD. 2010. Knock-in mutation reveals an essential role for focal adhesion kinase activity in blood vessel morphogenesis and cell motility-polarity but not cell proliferation. J Biol Chem 285: 21526-21536.

Lindsell CE, Shawber CJ, Boulter J, Weinmaster G. 1995. Jagged: A mammalian ligand that activates Notch1. Cell 80: 909-917.

Lubarsky B, Krasnow MA. 2003. Tube morphogenesis: Making and shaping biological tubes. Cell 112: 19-28.

Macara IG. 2004. Par proteins: Partners in polarization. Curr Biol 14: R160-R162.

Mailhos C, Modlich U, Lewis J, Harris A, Bicknell R, IshHorowicz D. 2001. Delta4, an endothelial specific notch ligand expressed at sites of physiological and tumor angiogenesis. Differentiation 69: 135-144.

Martinez Arias A, Zecchini V, Brennan K. 2002. CSL-independent Notch signalling: A checkpoint in cell fate decisions during development? Curr Opin Genet Dev 12: 524-533.

Matsuno K, Go MJ, Sun X, Eastman DS, Artavanis-Tsakonas S. 1997. Suppressor of Hairless-independent events in Notch signaling imply novel pathway elements. Development 124: 4265-4273.

Milano J, McKay J, Dagenais C, Foster-Brown L, Pognan F, Gadient R, Jacobs RT, Zacco A, Greenberg B, Ciaccio PJ. 2004. Modulation of notch processing by $\gamma$-secretase inhibitors causes intestinal goblet cell metaplasia and induction of genes known to specify gut secretory lineage differentiation. Toxicol Sci 82: 341-358.

Money TT, King RG, Wong MH, Stevenson JL, Kalionis B, Erwich JJ, Huisman MA, Timmer A, Hiden U, Desoye G, et al. 2007. Expression and cellular localisation of chloride intracellular channel 3 in human placenta and fetal membranes. Placenta 28: 429-436.

Morgan TH. 1917. The theory of the gene. Am Naturalist 51: $513-544$.
Nakatsu MN, Sainson RC, Aoto JN, Taylor KL, Aitkenhead M, Perez-del-Pulgar S, Carpenter PM, Hughes CC. 2003. Angiogenic sprouting and capillary lumen formation modeled by human umbilical vein endothelial cells (HUVEC) in fibrin gels: The role of fibroblasts and Angiopoietin-1. Microvasc Res 66: 102-112.

Nakatsu MN, Davis J, Hughes CC. 2007. Optimized fibrin gel bead assay for the study of angiogenesis. J Vis Exp 2007: 186.

Nofziger D, Miyamoto A, Lyons KM, Weinmaster G. 1999. Notch signaling imposes two distinct blocks in the differentiation of C2C12 myoblasts. Development 126: 1689-1702.

Noguera-Troise I, Daly C, Papadopoulos NJ, Coetzee S, Boland P, Gale NW, Lin HC, Yancopoulos GD, Thurston G. 2006. Blockade of Dll4 inhibits tumour growth by promoting non-productive angiogenesis. Nature 444: $1032-1037$.

Osmani N, Peglion F, Chavrier P, Etienne-Manneville S. 2010. Cdc42 localization and cell polarity depend on membrane traffic. J Cell Biol 191: 1261-1269.

Palomero T, McKenna K, O-Neil J, Galinsky I, Stone R, Suzukawa K, Stiakaki E, Kalmanti M, Fox EA, Caligiuri MA, et al. 2006. Activating mutations in NOTCH1 in acute myeloid leukemia and lineage switch leukemias. Leukemia 20: 1963-1966.

Parker LH, Schmidt M, Jin SW, Gray AM, Beis D, Pham T, Frantz G, Palmieri S, Hillan K, Stainier DY, et al. 2004. The endothelial-cell-derived secreted factor Egfl7 regulates vascular tube formation. Nature 428: 754-758.

Patel NS, Li JL, Generali D, Poulsom R, Cranston DW, Harris AL. 2005. Up-regulation of delta-like 4 ligand in human tumor vasculature and the role of basal expression in endothelial cell function. Cancer Res 65: 8690-8697.

Patel NS, Dobbie MS, Rochester M, Steers G, Poulsom R, Le Monnier K, Cranston DW, Li JL, Harris AL. 2006. Up-regulation of endothelial delta-like 4 expression correlates with vessel maturation in bladder cancer. Clin Cancer Res 12: 4836-4844.

Petroll WM, Jester JV, Barry-Lane P, Cavanagh HD. 1995. Assessment of $\mathrm{f}$-actin organization and apical-basal polarity during in vivo cat endothelial wound healing. Invest Ophthalmol Vis Sci 36: 2492-2502.

Pollack AL, Runyan RB, Mostov KE. 1998. Morphogenetic mechanisms of epithelial tubulogenesis: MDCK cell polarity is transiently rearranged without loss of cell-cell contact during scatter factor/hepatocyte growth factorinduced tubulogenesis. Dev Biol 204: 64-79.

Ponsioen B, van Zeijl L, Langeslag M, Berryman M, Littler D, Jalink K, Moolenaar WH. 2009. Spatiotemporal regulation of chloride intracellular channel protein CLIC4 by RhoA. Mol Biol Cell 20: 4664-4672.

Redhead C, Sullivan SK, Koseki C, Fujiwara K, Edwards JC. 1997. Subcellular distribution and targeting of the intracellular chloride channel 64. Mol Biol Cell 8: 691-704.

Ridgway J, Zhang G, Wu Y, Stawicki S, Liang WC, Chanthery Y, Kowalski J, Watts RJ, Callahan C, Kasman I, et al. 2006. Inhibition of Dll4 signalling inhibits tumour growth by deregulating angiogenesis. Nature 444: 1083-1087.

Rizzo P, Osipo C, Foreman K, Golde T, Osborne B, Miele L. 2008. Rational targeting of Notch signaling in cancer. Oncogene 27: 5124-5131. 
Tips, Stalks, and Tubes

Rupp PA, Little CD. 2001. Integrins in vascular development. Circ Res 89: 566-572.

Ryeom SW. 2011. The cautionary tale of side effects of chronic Notch1 inhibition. J Clin Invest 121: 508-509.

Scehnet JS, Jiang W, Kumar SR, Krasnoperov V, Trindade A, Benedito R, Djokovic D, Borges C, Ley EJ, Duarte A, et al. 2007. Inhibition of Dll4-mediated signaling induces proliferation of immature vessels and results in poor tissue perfusion. Blood 109: 4753-4760.

Schmidt T, Carmeliet P. 2010. Blood-vessel formation: Bridges that guide and unite. Nature 465: 697-699.

Searfoss GH, Jordan WH, Calligaro DO, Galbreath EJ, Schirtzinger LM, Berridge BR, Gao H, Higgins MA, May PC, Ryan TP. 2003. Adipsin, a biomarker of gastrointestinal toxicity mediated by a functional $\gamma$-secretase inhibitor. J Biol Chem 278: 46107-46116.

Serbedzija GN, Flynn E, Willett CE. 1999. Zebrafish angiogenesis: A new model for drug screening. Angiogenesis 3: 353-359.

Shawber C, Boulter J, Lindsell CE, Weinmaster G. 1996a. Jagged2: A serrate-like gene expressed during rat embryogenesis. Dev Biol 180: 370-376.

Shawber C, Nofziger D, Hsieh JJ, Lindsell C, Bogler O, Hayward D, Weinmaster G. 1996b. Notch signaling inhibits muscle cell differentiation through a CBF1-independent pathway. Development 122: 3765-3773.

Shawber CJ, Das I, Francisco E, Kitajewski J. 2003. Notch signaling in primary endothelial cells. Ann NY Acad Sci 995: $162-170$.

Sheldon H, Heikamp E, Turley H, Dragovic R, Thomas P, Oon CE, Leek R, Edelmann M, Kessler B, Sainson RCA, et al. 2010. New mechanism for Notch signaling to endothelium at a distance by Delta-like 4 incorporation into exosomes. Blood 116: 2385-2394.

Shojaei F, Wu X, Malik AK, Zhong C, Baldwin ME, Schanz S, Fuh G, Gerber HP, Ferrara N. 2007. Tumor refractoriness to anti-VEGF treatment is mediated by $\mathrm{CD} 11 \mathrm{~b}+\mathrm{Gr} 1+$ myeloid cells. Nat Biotechnol 25: 911-920.

Singh H, Cousin MA, Ashley RH. 2007. Functional reconstitution of mammalian "chloride intracellular channels" CLIC1, CLIC4 and CLIC5 reveals differential regulation by cytoskeletal actin. FEBS J 274: 6306-6316.

Small D, Kovalenko D, Kacer D, Liaw L, Landriscina M, Di Serio C, Prudovsky I, Maciag T. 2001. Soluble Jagged 1 represses the function of its transmembrane form to induce the formation of the Src-dependent chord-like phenotype. J Biol Chem 276: 32022-32030.

Stahl A, Connor KM, Sapieha P, Chen J, Dennison RJ, Krah NM, Seaward MR, Willett KL, Aderman CM, Guerin KI, et al. 2010. The mouse retina as an angiogenesis model. Invest Ophthalmol Vis Sci 51: 2813-2826.

Stratman AN, Saunders WB, Sacharidou A, Koh W, Fisher KE, Zawieja DC, Davis MJ, Davis GE. 2009. Endothelial cell lumen and vascular guidance tunnel formation requires MT1-MMP-dependent proteolysis in 3-dimensional collagen matrices. Blood 114: 237-247.

Strilic B, Kucera T, Eglinger J, Hughes MR, McNagny KM, Tsukita S, Dejana E, Ferrara N, Lammert E. 2009. The molecular basis of vascular lumen formation in the developing mouse aorta. Dev Cell 17: 505-515.
Stupack DG, Cheresh DA. 2002. ECM remodeling regulates angiogenesis: Endothelial integrins look for new ligands. Sci STKE 2002: e7.

Stupack DG, Cheresh DA. 2004. Integrins and angiogenesis. Curr Top Dev Biol 64: 207-238.

Suh KS, Mutoh M, Gerdes M, Yuspa SH. 2005. CLIC4, an intracellular chloride channel protein, is a novel molecular target for cancer therapy. J Investig Dermatol Symp Proc 10: 105-109.

Suh KS, Crutchley JM, Koochek A, Ryscavage A, Bhat K, Tanaka T, Oshima A, Fitzgerald P, Yuspa SH. 2007. Reciprocal modifications of CLIC4 in tumor epithelium and stroma mark malignant progression of multiple human cancers. Clin Cancer Res 13: 121-131.

Sullivan DC, Bicknell R. 2003. New molecular pathways in angiogenesis. Br J Cancer 89: 228-231.

Tanjore H, Zeisberg EM, Gerami-Naini B, Kalluri R. 2008. $\beta 1$ integrin expression on endothelial cells is required for angiogenesis but not for vasculogenesis. Dev Dyn 237: $75-82$.

Thomas U, Speicher SA, Knust E. 1991. The Drosophila gene Serrate encodes an EGF-like transmembrane protein with a complex expression pattern in embryos and wing discs. Development 111: 749-761.

Thurston G, Noguera-Troise I, Yancopoulos GD. 2007. The Delta paradox: DLL4 blockade leads to more tumour vessels but less tumour growth. Nat Rev Cancer 7: 327-331.

Tung JJ, Kitajewski J. 2010. Chloride intracellular channel 1 functions in endothelial cell growth and migration. J Angiogenes Res 2: 23.

Tung JJ, Hobert O, Berryman M, Kitajewski J. 2009. Chloride intracellular channel 4 is involved in endothelial proliferation and morphogenesis in vitro. Angiogenesis 12: 209-220.

Uemura A, Kusuhara S, Katsuta H, Nishikawa S. 2006. Angiogenesis in the mouse retina: A model system for experimental manipulation. Exp Cell Res 312: 676-683.

Ulmasov B, Bruno J, Woost PG, Edwards JC. 2007. Tissue and subcellular distribution of CLIC1. BMC Cell Biol 8: 8 .

Ulmasov B, Bruno J, Gordon N, Hartnett ME, Edwards JC. 2009. Chloride intracellular channel protein-4 functions in angiogenesis by supporting acidification of vacuoles along the intracellular tubulogenic pathway. Am J Pathol 174: $1084-1096$.

Uyttendaele H, Marazzi G, Wu G, Yan Q, Sassoon D, Kitajewski J. 1996. Notch4/int-3, a mammary protooncogene, is an endothelial cell-specific mammalian Notch gene. Development 122: 2251-2259.

Vässin H, Bremer KA, Knust E, Campos-Ortega JA. 1987. The neurogenic gene Delta of Drosophila melanogaster is expressed in neurogenic territories and encodes a putative transmembrane protein with EGF-like repeats. EMBO J 6: 3431-3440.

Wang Y, Kaiser MS, Larson JD, Nasevicius A, Clark KJ, Wadman SA, Roberg-Perez SE, Ekker SC, Hackett PB, McGrail M, Essner JJ. 2010. Moesin1 and Ve-cadherin are required in endothelial cells during in vivo tubulogenesis. Development 137: 3119-3128.

Wegner B, Al-Momany A, Kulak SC, Kozlowski K, Obeidat M, Jahroudi N, Paes J, Berryman M, Ballermann BJ. 2010. CLIC5A, a component of the ezrin-podocalyxin 


\section{J.J. Tung et al.}

complex in glomeruli, is a determinant of podocyte integrity. Am J Physiol Renal Physiol 298: F1492-F1503.

Weinmaster G. 1998. Notch signaling: Direct or what? Curr Opin Genet Dev 8: 436-442.

Weinmaster G, Roberts VJ, Lemke G. 1991. A homolog of Drosophila Notch expressed during mammalian development. Development 113: 199-205.

Weinmaster G, Roberts VJ, Lemke G. 1992. Notch2: A second mammalian Notch gene. Development 116: 931-941.

Weis SM, Lindquist JN, Barnes LA, Lutu-Fuga KM, Cui J, Wood MR, Cheresh DA. 2007. Cooperation between VEGF and $\beta 3$ integrin during cardiac vascular development. Blood 109: 1962-1970.

Weng AP, Ferrando AA, Lee W, Morris JP, Silverman LB, Sanchez-Irizarry C, Blacklow SC, Look AT, Aster JC. 2004. Activating mutations of NOTCH1 in human T cell acute lymphoblastic leukemia. Science 306: $269-271$.

Wharton KA, Johansen KM, Xu T, Artavanis-Tsakonas S. 1985. Nucleotide sequence from the neurogenic locus notch implies a gene product that shares homology with proteins containing EGF-like repeats. Cell 43: 567-581.
Wolff JR, Bar T. 1972. "Seamless" endothelia in brain capillaries during development of the rat's cerebral cortex. Brain Res 41: 17-24.

Wu Y, Cain-Hom C, Choy L, Hagenbeek TJ, de Leon GP, Chen Y, Finkle D, Venook R, Wu X, Ridgway J, et al. 2010. Therapeutic antibody targeting of individual Notch receptors. Nature 464: 1052-1057.

Yan M, Callahan CA, Beyer JC, Allamneni KP, Zhang G, Ridgway JB, Niessen K, Plowman GD. 2010. Chronic DLL4 blockade induces vascular neoplasms. Nature 463: E6-E7.

Zeeb M, Strilic B, Lammert E. 2010. Resolving cell-cell junctions: lumen formation in blood vessels. Curr Opin Cell Biol 22: 626-632.

Zhong TP, Childs S, Leu JP, Fishman MC. 2001. Gridlock signalling pathway fashions the first embryonic artery. Nature 414: 216-220.

Zovein AC, Luque A, Turlo KA, Hofmann JJ, Yee KM, Becker MS, Fassler R, Mellman I, Lane TF, Iruela-Arispe ML. 2010. $\beta 1$ integrin establishes endothelial cell polarity and arteriolar lumen formation via a Par3-dependent mechanism. Dev Cell 18: 39-51. 


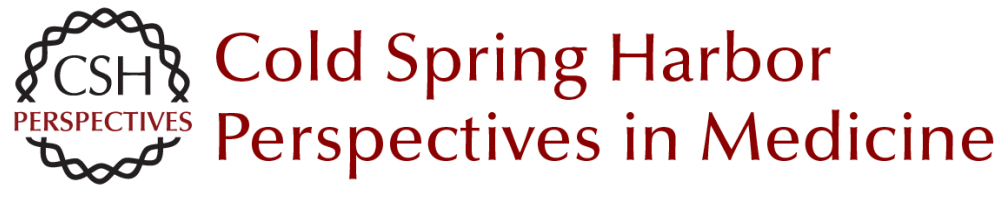

\title{
Tips, Stalks, Tubes: Notch-Mediated Cell Fate Determination and Mechanisms of Tubulogenesis during Angiogenesis
}

\author{
Jennifer J. Tung, Ian W. Tattersall and Jan Kitajewski
}

Cold Spring Harb Perspect Med 2012; doi: 10.1101/cshperspect.a006601 originally published online October 6, 2011

\section{Subject Collection Angiogenesis}

\section{Extracellular Matrix Regulation of Vascular}

Morphogenesis, Maturation, and Stabilization George E. Davis and Scott S. Kemp

Endothelial Cell-Pericyte Interactions in the

Pathogenesis of Cerebral Cavernous

Malformations (CCMs)

Wang Min and Jenny Huanjiao Zhou

Lymphatic Clearance and Pump Function Jerome W. Breslin

Platelets and (Lymph)angiogenesis Harvey G. Roweth and Elisabeth M. Battinelli

Modeling Brain Vasculature Immune Interactions In Vitro

Ruth Lyck, Hideaki Nishihara, Sidar Aydin, et al.

Human Endothelial Colony-Forming Cells Juan M. Melero-Martin

The Beauty and Complexity of Blood Vessel Patterning

Victoria L. Bautch and Yoh-suke Mukouyama

Endothelialitis, Microischemia, and

Intussusceptive Angiogenesis in COVID-19

Steven J. Mentzer, Maximilian Ackermann and

Danny Jonigk
Regulation of the Blood-Brain Barrier in Health and Disease

Cara C. Rada, Kanako Yuki, Jie Ding, et al.

Targeting Angiogenesis via Resolution of Inflammation

Abigail G. Kelly and Dipak Panigrahy

Notch Signaling in the Vasculature: Angiogenesis and Angiocrine Functions

Sana S. Hasan and Andreas Fischer

Signal Transduction and Gene Regulation in the

Endothelium

Michel V. Levesque and Timothy Hla

Buttons and Zippers: Endothelial Junctions in

Lymphatic Vessels

Peter Baluk and Donald M. McDonald

Endothelial Cell Fate Determination: A Top Notch Job in Vascular Decision-Making

L.A. Naiche, Stephanie R. Villa and Jan K. Kitajewski

Leukocyte Trafficking in Lymphatic Vessels Aline Bauer, Hazal Tatliadim and Cornelia Halin

Lymphatic Tissue and Organ Engineering for In Vitro Modeling and In Vivo Regeneration Anna M. Kolarzyk, Gigi Wong and Esak Lee

For additional articles in this collection, see http://perspectivesinmedicine.cshlp.org/cgi/collection/ 